Charles Merriam had an uncanny perception of emerging trends and great skill in putting young men to work in promising fields. His eye was always on the horizon, and he was always busy searching for ways and means of ferrying mankind to a happier destination. His host of friends and students will remember him as a man who enlivened any gathering of which he was a member. He was friendly, genial, fond of company and conversation, and full of wisdom. He had an extraordinary capacity for commanding the respect, the loyalty, and the affection of those who knew him. Perhaps no political scientist of his generation exerted a greater influence, not only within his own field but upon the constructive development of the social sciences and their contribution to public affairs.-LEONARD D. White.

Julius Turner, associate professor of political science at Allegheny College, died December 24, 1952, at the age of thirty. Already he had won recognition as one of the most promising young scholars in the field of American politics. His published work reflected skill and ingenuity in analysis and both imagination and respect for data in interpretation. At the time of his death he had under way, with the aid of a Social Science Research Council fellowship, an analysis of congressional elections with a view toward a more complete understanding of the extent and limits of party competition. Fragments of this work, some of which were left in sufficiently finished form for publication, indicate that it would have compelled considerable modification of conventional theories of the party system.

Professor Turner had received his Ph.D. degree in 1950 from the Johns Hopkins University, where he also served as a junior instructor. His doctoral thesis, initiated under the direction of V. O. Key, Jr., was published under the title, Party and Constituency: Pressures on Congress. He taught at Boston University before moving to Allegheny. He had achieved already an unusual mastery of the art of teaching, and had gone far in establishing mutually valuable friendships in his profession. His untimely death is the occasion of loss and regret which extend far beyond relationships which are merely personal. In evidence of this fact, a number of his friends at different institutions throughout the country have instituted at the Johns Hopkins University a Julius Turner Award, to be given annually for the most outstanding essay submitted in the field of political science.Carl B. Swisher.

\title{
SPECIAL ANNOUNCEMENT
}

\section{Next Annual Meeting of the Association}

The 1953 meeting of the American Political Science Association will be held at the Statler and Mayflower Hotels in Washington, D. C., on September 10-12. Professor John Gange of the Woodrow Wilson School of Foreign Affairs, University of Virginia, has accepted the chairmanship of the program committee. Mrs. Kathryn Stone is to be chairman of the local arrangements committee. 